Winter 2015

\title{
Breaking the Curse: A Multilayered Regulatory Approach
}

Hunter DeKoninck

Indiana University Maurer School of Law, hgdekoni@indiana.edu

Follow this and additional works at: https://www.repository.law.indiana.edu/ijgls

Part of the International Business Commons, International Law Commons, Natural Resources Law Commons, and the Oil, Gas, and Mineral Law Commons

\section{Recommended Citation}

DeKoninck, Hunter (2015) "Breaking the Curse: A Multilayered Regulatory Approach," Indiana Journal of Global Legal Studies: Vol. 22 : Iss. 1 , Article 8.

Available at: https://www.repository.law.indiana.edu/ijgls/vol22/iss1/8

This Note is brought to you for free and open access by the Law School Journals at Digital Repository @ Maurer Law. It has been accepted for inclusion in Indiana Journal of Global Legal Studies by an authorized editor of Digital Repository@Maurer Law. For more information, please contactrvaughan@indiana.edu.

\section{$\Psi$}

JEROME HALL LAW LIBRARY

INDIANA UNIVERSITY

Maurer School of Law
Bloomington 


\title{
Breaking the Curse: A Multilayered Regulatory Approach
}

\author{
HUNTER DEKONINCK ${ }^{*}$
}

\begin{abstract}
Eastern Africa has been plagued for generations with what Richard Auty considers "The Resource Curse." This curse, translated into modern economic tragedies, is the exploitive extraction and use of precious minerals from Eastern Africa, specifically the Democratic Republic of the Congo (DRC). As a result of attempts to combat the international market that perpetuates this curse, Section 1502 of the Dodd-Frank Wall Street Reform Act, largely in response to human rights activism, passed into law a provision requiring companies to account to the Securities and Exchange Commission (SEC) for their use of certain listed foreign minerals. Although such regulation is economically stifling for companies, it is appropriately outweighed by an international human rights interest. Currently, this legislative and regulatory measure is insufficient because it feebly regulates manufacturers in an afterextraction market without an extraction-level regulation in Eastern Africa. Therefore, to legitimize Section 1502 and to appropriately aid U.S. companies in their compliance with Section 1502, the African Union, or a coalition of governments and organizations, must establish a certification process by which minerals are lawfully extracted and formally sold in the international market. This would establish both an extraction-level and post-extraction-level regulation that work in tandem. Implementing one without the other will not begin to resolve this international crisis.
\end{abstract}

* Executive Business Editor, Indiana Journal of Global Legal Studies, Volume 22; JD 2015, Indiana University Maurer School of Law; BA 2012, Wake Forest University. This Note is informed by my experience studying and working in African politics, including working in the U.S. embassy in Abuja, Nigeria; receiving a fully funded grant to conduct independent research on the rehabilitation of child soldiers in Northern Uganda; and studying Islamic political culture in central Morocco. I would like to thank Professor Hannah Buxbaum for her valuable contributions to this Note and her continued support in my research.

Indiana Journal of Global Legal Studies Vol. 22 \#1 (Winter 2015)

(c) Indiana University Maurer School of Law 


\section{INTRODUCTION}

The Democratic Republic of the Congo (DRC) is, by land area, the eleventh largest country in the world. ${ }^{1}$ With dense forests and an abundant ecosystem, it sits on the equator stretching across SubSaharan Africa. To the layman, the DRC may not seem to be a strategic swath of land. Indeed, many formulate their conception of this nation around despondent and clichéd Heart of Darkness impressions. Others may discredit the nation's potential after years of continuous reports of conflict. However, contrary to this belief, with some of the world's largest reservoirs of gold, copper, zinc, tantalum, coltan, cobalt, tin, and diamonds, the "total mineral wealth of the . . DRC is estimated to be some $\$ 24$ trillion-equivalent to the GDP of [the European Union] and the US combined." 2 In fact, today the Congolese mining industry accounts for 80 percent of national exports, 72 percent of the national budget, and 28 percent of the Gross Domestic Product (GDP) of the DRC. $^{3}$ Historically, this wealth has been realized and exploited by colonial leaders such as King Leopold of Belgium; ${ }^{4}$ however, rather than developing the Congo economically, their business practices institutionalized slavery, perpetuated poverty, and authorized murder.

George Nzongola-Ntalaja, a renowned scholar in African politics, states the unfortunate interest in the Congo over the years. He maintains, "the strategic objective since 1884 has remained the same. It is, above all, to prevent the country from falling into the wrong hands, politically speaking, so as to maximize the extraction of its bountiful natural wealth to the benefit of these dominant interests." 5

1. The World Factbook, CENTRAL INTELligenCE AGENCY, https://www.cia.gov/library/ publications/the-world-factbook/geos/cg.html (last visited Jan. 9, 2014).

2. M.J. Morgan, DR Congo's \$24 Trillion Fortune, AFRICAN BUSINESS (Feb. 1, 2009), http://www.thefreelibrary.com/DR+Congo\%27s+\$24+trillion+fortune.-a0193800184.

3. Laura E. Seay, What's Wrong with Dodd-Frank 1502? 8 (Ctr. for Global Development, Working Paper No. 284, 2012) (quoting Aloys Tegera, Roundtable on Conflict Minerals Legislation, MAKEITFAIR CAMPAIGN (May 2011), available at http://makeitfair.org/en/the-facts/reports/roundtable-on-conflict-minerals-legislation/view).

4. King Leopold was the King of Belgium from 1865-1909. After outmaneuvering other European powers during the scramble for Africa, King Leopold established the Congo Free State in 1885, giving himself personal reign over the territory. King Leopold required the Congolese by law to supply labor, rubber, and ivory to the King's agents. As a result of murder, starvation, and disease, the Congolese population plummeted from 2030 million people to 8.5 million during this colonial era. GEORGES NzoNGOLA-NTALAJA, The CONGo FROM LeOPOLD TO KABILA: A PEOPLE'S History 20-23 (2002).

5. Id. at 258 . 
Historically, human rights activists have responded to this exploitive view of the DRC by advocating and demanding change in trade practices and instituting protective measures for the Congolese. For example, in the early twentieth century, the Congo Reform Association (CRA) publicly reported on King Leopold's years of brutal practices in the Congo, describing the ruthless nature with which he and his employees treated the Congolese. ${ }^{6}$ Armed with these reports, European human rights activists lobbied and were successful in convincing the Belgian government to purchase the Congo from King Leopold, thus ending his personal corporate reign over what he had long treated as his private enterprise. ${ }^{7}$ This purchase offered an opportunity to release the Congolese from the bondage of despotic corporate interests and set the country on a path of economic efficiency and eventual independence. However, such domestic changes within Belgium were not met with substantive changes in the Congo itself. Rather, forced labor and death continued under the guise of a Belgiancolonized state. ${ }^{8}$

A second example of a lost opportunity to change circumstances in the DRC was when the Congo finally acquired independence in 1960. During the 1960s, "Human Rights" activism took center stage in colonized territories. ${ }^{9}$ Activists in third-world countries began using phrases like inalienable rights, self-determination, and natural rights. ${ }^{10}$ With such powerful movements, Congolese activists were hopeful that freedom from colonial devices would create change for the Congolese people. In 1960 the new democratically-elected Prime Minister Patrice Lumumba established a promising movement focused on a "pan-African ideal of African unity and the Bandung principle of 'positive neutralism' or non-alignment" during the Cold War. ${ }^{11}$ These ideals, coupled with promises of sustainable political and economic independence, led many to believe that the Congo would be brought out of the depths in which it

6. Id. at $23-26$.

7. John Burchill, Out of the Heart of Darkness: A New Regime for Controlling Resource Extraction in the Congo, 10 ASPER REv. INT'L. BUS. \& TRADE L. 99, 106 (2010). Activists George Washington Williams, Reverend William Henry Sheppard, William Morrison, Roger Casement, and Hezekiah Andrew Shanu are largely credited with starting the human rights movement centered around the Congo, and in doing so, they led the charge in combatting King Leopold's practices within the Congo. NZONGOLA-NTALAJA, supra note 4 , at $23-26$.

8. Burchill, supra note 7 , at 106.

9. See generally, Kenneth Cmiel, The Recent History of Human Rights, 109 AM. HIST. REV. 117 (2004) (discussing the rapid growth of the human rights movement from the 1990 s to the present day).

10. See id. at 123.

11. NZONGOLA-NTALAJA, supra note 4 , at 96 . 
had been trapped.12 However, President Lumumba was assassinated and later replaced by the dictator General Mobutu in a 1965 coup d'état backed by the United States. ${ }^{13}$ Then, bound to serve Western interests, President Mobutu ensured that powerful corporations like Union Minière maintained their foothold in the Congo, and many corporate holdings were sold off to Belgian companies, thus perpetuating corporate interests in the DRC. ${ }^{14}$

Finally, the failed policies of the World Trade Organization's (WTO) 2001 Doha Development Goals illustrate a third example of a missed opportunity to positively influence the DRC. The WTO and its 153 members (including the DRC) promulgated policies that freed the flow of trade in an effort to promote global stability, alleviate poverty, and increase standards of living. ${ }^{15}$ However, these international policies have all failed to enhance economic efficiency, health, and welfare in the Congo. ${ }^{16}$

As well-intended as their policies may have been, human rights activists have historically motivated change only within their own nations or within the international community, and such instances have not led to measurable change for the Congolese people. Thus, in learning from these missed opportunities of historical international efforts, this Note will advocate the need for a Congolese-centered and Congolese-originated solution.

Today, the humanitarian crisis in the DRC remains intractable. Observers within the Congo have concluded that, abuse of the trade of conflict minerals fund rebel conflicts and perpetuate human atrocities. ${ }^{17}$ To further buttress the substantial human rights interest surrounding these mines, one must consider the context of the regional crisis. The

12. See id.

13. Anne DeVoe, Carrying a Piece of Congo in Our Pockets: Global Complicity to Congo's Sexual Violence and the Conflict Minerals Trade, 10 SEATTLE J. For Soc. JUST. 463, 472 (2011).

14. Burchill, supra note 7 , at 106 .

15. See id. at 111 .

16. See id. at 112 .

17. As is the case for many combatants in the region, the militarization of mining sites in the Kivu region of the DRC has been a major source of funding for the FDLR (Democratic Forces for the Liberation of Rwanda), a major military organization in Eastern DRC. Such funding aids in the acquisition of weapons, food, and payment for soldiers. U.N. Group of Experts on Democratic Republic of Congo, Letter dated Nov. 12, 2012 from the Chair of the Security Council Committee established pursuant to resolution 1533 (2004) concerning the Democratic Republic of the Congo addressed to the President of the Security Council, I 96, U.N. Doc. S/2012/843 (Nov. 15, 2012) [hereinafter U.N. Group of Experts]. Additionally, President Kabila's mining ban in 2011, a possible reaction to $\$ 1502$ of Dodd-Frank, has led to depressed economic circumstances in the DRC. See id. at ๆ $223-239$. 
Second Congo War, beginning in 1998, was the deadliest conflict since World War II, with over 5.4 million casualties. ${ }^{18}$ The severity of this conflict can be attributed to a perfect storm of geopolitical events: with mounting political tensions in the region, President Mobutu of the DRC (then named Zaire) struggled to protect his isolationist policies from surrounding nations interested in Congolese treasures. Mobutu employed repressive dictatorial policies, which fueled tensions among Congolese people. Ultimately, "a coalition of African states, including Angola, Eritrea, Rwanda, Tanzania, Uganda and Zimbabwe" supported a coup d'état to overthrow Mobutu. ${ }^{19}$

Additionally, the neighboring Rwandan genocide ${ }^{20}$ forced over one million Rwandan Hutus to seek refuge in the Eastern Congo. ${ }^{21}$ Then, in 1996 during the genocide, Rwandan Tutsi-led forces deployed troops into the Eastern Congo with the intent of capturing the Hutu militants who participated in the genocide; however, this incursion led to largescale massacres of both civilian and militant Hutus, sending the Eastern DRC into a severe state of turmoil. ${ }^{22}$

Ultimately, the unrest created by Mobutu's policies, further amplified by the response to the Rwandan genocide, caused the outbreak of the Second Congo War, which involved fighting among five rebel subgroups and the Congolese, Ugandan, and Rwandan militaries. ${ }^{23}$ Although the original causes for conflict in the Congoland, ethnic identity, power, and wealth-are still at play, "the main fuel that allows the violence to continue is the roughly " $\$ 180$ million a year from trading in minerals." 24 Due to the violence associated with these conflict minerals, ongoing fighting since the official end of the Congo war in 2003 continues to claim 1,500 lives per day from warrelated causes. ${ }^{25}$ Conflict in the Eastern Congo has also contributed to

18. IRC Study Shows Congo's Neglected Crisis Leaves 5.4 Million Dead; Peace Deal in N. Kivu, Increased Aid Critical to Reducing Death Toll, INT'L RESCUE COMM., http://www.rescue.org/news/irc-study-shows-congos-neglected-crisis-leaves-54-milliondead-peace-deal-n-kivu-increased-aid--4331 (last visited Dec. 22, 2013).

19. NZONGOLA-NTALAJA, supra note 4 , at 225 .

20. Historical ethnic tensions between Rwandan Hutus and Tutsis exploded after Hutu extremists assassinated Rwandan President Habyarimana. In the following three months, between 800,000 and one million people were killed in a genocide. Both Western nations and the U.N. refrained from humanitarian intervention, and the genocide finally ended when Tutsi forces regained control of the country. See id. at 222-23.

21. Id. at 224 .

22. See id.

23. See id. at 229-31.

24. DeVoe, supra note 13 , at 480 .

25. See Robin Wright Penn \& John Prendergast, Cell Phones and Congo's War Against Women, SAN Francisco CHRON. (Jan. 7, 2009, 4:00 AM), http:/www.sfgate.com/opinion/ article/Cell-phones-and-Congo-s-war-against-women-3177605.php. 
acute malnutrition of 10 to 30 percent of the population. ${ }^{26}$ Put simply, U.N. Under-Secretary-General Jan Egeland considered this conflict to be the "biggest, most neglected humanitarian emergency in the world today." 27

In recent years, the Congolese have voiced their concerns in Washington, D.C., stimulating reform in U.S. trade practices and relations with the Eastern Congo. In the midst of the highly controversial Wall Street Reform and Consumer Protection Act, also called the Dodd-Frank Bill, ${ }^{28}$ a small provision was added into the "Other Provisions" section of the bill. ${ }^{29}$ There, at the end of the bill, hides a law that dramatically changes economic relations with the DRC for better or for worse. Section 1502 requires issuers "that file reports with the Commission under Section 13(a) or Section 15(d) of the Exchange Act" to report to the Securities and Exchange Commission (SEC) their use of minerals originating in East Africa. ${ }^{30}$ This bill requires companies to identify and disclose the origins of such minerals to prove that, if originating from the DRC or its adjoining neighbors, the minerals are conflict-free. As we will see, this bill will have unintended consequences in the DRC and its objective will remain elusive until regulatory measures within the Congo are implemented.

26. INT'L CRISIS GRP., AFRICA REPORT No. 56, The KrVUS: The ForgotTen CRUCIBLE OF THE CONGO CONFLICT, 13-14 (2003), available at http://www.crisisgroup.org/ /medial Files/africa/central-africa/dr-congo/The\%20Kivus\%20The\%20Forgotten $\% 20 \mathrm{Crucible} \% 20$ of $\% 20$ the $\% 20$ Congo\%20Conflict.pdf.

27. Eastern DR of Congo Surpasses Darfur as Biggest, Most Neglected Emergency-UN Relief Official, UNITED NATIONS NEws CENTRE, (Mar. 16, 2005), http://www.un.org/apps/ news/story.asp?NewsID $=13675 \& \mathrm{Cr}=$ democrati\#.UoJhcKV5luY.

28. Dodd-Frank is the United States legislative response to the collapse of the world financial market in 2008 and the credit crisis suffered by the U.S. banking market since that time. The scope of this bill was to regulate federal financial regulatory agencies and almost every aspect of the financial industry. Critics have argued that the scope was not wide enough to prevent another financial crisis, while other critics argued that the bill unduly restricts the financial industry. William Sweet, Dodd-Frank Act Becomes Law, HaRV. L. SCh. F. ON CoRP. Governance \& Fin. REg. (July 21, 2010, 11:49 AM), http://blogs.law.harvard.edu/corpgov/2010/07/21/dodd-frank-act-becomes-law/.

29. H.R. 4173, 111th Cong. § 1502 (2010).

30. Conflict Minerals, 77 Fed. Reg. 56,274, 56,285 (Sept. 12, 2012) (to be codified at 17 C.F.R. $\$ \S 240,249 b)$. 


\section{THE LAW AND ECONOMICS OF THE PROBLEM}

\section{A. The Law-Section 1502 of the Dodd-Frank Wall Street Reform and Consumer Protection Act}

Traditionally, it is rare for human rights activists to have the political capital necessary to pass legislation adverse to corporate interests. Political scientists Lawrence Jacobs and Benjamin Page used "three distinct types of statistical models [to indicate] that business[es] [have] a strong, consistent, and, at times, lopsided influence upon U.S. foreign policy." 31 Their study found that businesses, rather than the public, exert the most influence over policy-makers. ${ }^{32}$ However, there are a few examples of such laws passing through Congress despite their adverse impact on corporate interests, such as the Alien Tort Statute ${ }^{33}$ and the Foreign Corrupt Practices Act. ${ }^{34}$ Section 1502, on the other hand, was a law that was swept in with the omnibus bill-DoddFrank-that, at its core, was already aimed to target corporate practices in the United States.

Section 1502 is, what I will call, a trade-level solution, intended to influence trade practices through how U.S. businesses acquire particular minerals from conflict mines. Section 1502's explicit requirements direct the SEC to develop and promulgate a rule requiring greater transparency and disclosure regarding the conflict minerals coming out of the DRC and its neighboring countries. ${ }^{35}$

In 2012, the SEC issued the Final Rule, which requires companies to make "public and disclose annually to the Securities and Exchange Commission if the minerals in their products originated or may have originated in Congo," which will "ensure activities involving such minerals did not finance or benefit armed groups." 36 The Final Rule regulates the use of conflict minerals including: "columbite-tantalite (used in the manufacture of condensers, micro-electronic technology, such as chips and processors, cell phones, nuclear reactors, and highly heat-tolerant varieties of steel), cassiterite (the major ore used in making tin), wolframite (the principle ore in tungsten, used in

31. Lawrence Jacobs \& Benjamin Page, Business Versus Public Influence in U.S. Foreign Policy, in AMERICAN ForeIGn Policy 343, 360 (G. John Ikenberry ed., 6th ed. 2011).

32. See id. at 353-55.

33. 28 U.S.C. $\S 1350$ (2014).

34. 15 U.S.C. $\S 78 \mathrm{dd} \cdot 1$ (2014).

35. Nat'l Ass'n of Mfrs. v. SEC, 956 F. Supp. 2d 43, 46 (D.D.C. 2013).

36. 156 CoNG. REC. 76, S3976 (daily ed. May 19, 2010) (statement of Sen. Feingold, Chairman of Senate Subcommittee on Africa). 
numerous electrical items), gold, and any other mineral" that the Secretary of State determines is financing conflict in the DRC. ${ }^{37}$

The Final Rule requires a three-step process for companies to comply with Section 1502.38 First, the "issuer"39 must determine whether it is subject to the rule. The rule's scope "includes issuers whose conflict minerals are necessary to the functionality or production of a product manufactured or contracted by that issuer to be manufactured." 40 The rule contains no de minimus exception, so the rule "applies to issuers who use very small amounts of the conflict minerals." 41 The rule not only extends to those who directly manufacture products with such minerals, but also to issuers who contract for the manufacture of such products. ${ }^{42}$

If the issuer meets this definition it moves to the second step, in which the business must inquire as to the origins of the mineral:

[T]o satisfy the reasonable country of origin inquiry requirement, an issuer must conduct an inquiry regarding the origin of its conflict minerals that is reasonably designed to determine whether any of its conflict minerals originated in the Covered Countries or are from recycled or scrap sources, and must perform the inquiry in good faith. ${ }^{43}$

The minerals are only considered conflict minerals, for the purposes of this law, if they are sourced from the following countries: the Democratic Republic of the Congo, Angola, Burundi, Central African Republic, the Republic of the Congo, Rwanda, South Sudan, Tanzania, Uganda, and Zambia. ${ }^{44}$

Finally, the third step is to conduct due diligence and file with the SEC a specialized disclosure, Conflict Minerals Report, and an Audit Opinion. ${ }^{45}$ This step "requires such an issuer to exercise due diligence

37. Mallory Owen, The Limits of Economic Sanctions Under International Humanitarian Law: The Case of the Congo, 48 TEX. INT'L L.J. 103, 110-11 (2012).

38. Conflict Minerals, 77 Fed. Reg. at 56,279.

39. The Rule applies to issuers that "file reports with the Commission under Section 13(a) or 15(c) of the Exchange Act." Nat'l Ass'n of Mfrs., 956 F. Supp. 2d at 48.

40. Conflict Minerals, 77 Fed. Reg. at 56,279.

41. Nat'l Ass'n of Mfrs. v. SEC, 748 F.3d 359, 363 (D.C. Cir. 2014).

42. Id.

43. Conflict Minerals, 77 Fed. Reg. at $56,274$.

44. Decision Tree, PRICE WATERHOUSE COOPERS LLP, http://www.pwc.com/en_US/us/ audit-assurance-services/assets/pwc-conflict-minerals-decision-tree.png (last visited Aug. 3, 2014).

45. Conflict Minerals, 77 Fed. Reg. at 56,274. 
on the source and chain of custody of its conflict minerals and provide a Conflict Minerals Report describing its due diligence measures, among other matters." 46 The Conflict Minerals Report must describe the due diligence measures taken by the entity, and it must list the "products manufactured or contracted to be manufactured that are not DRC conflict free." 47 The product is deemed conflict-free if any minerals did not "directly or indirectly finance or benefit armed groups" in the Covered Countries. ${ }^{48}$ However, if the minerals are found to be conflict minerals, the issuer must disclose that fact in the report it files with the SEC, and must also post the report on its own website. ${ }^{49}$ This due diligence requirement becomes the SEC's mechanism by which it will be able to track the source and chain of custody of the conflict mineral. In essence, because Congress knows very little about the chain of custody close to the mines in the Congo, SEC reporting will act as a large factfinding mission that requires businesses to gather data so that more appropriate regulation may be administered in the future. ${ }^{50}$

However, the requirement of an issuer to publicly disclose to consumers on its website that its product includes DRC conflict minerals has recently been found to violate the issuer's First Amendment rights. ${ }^{51}$ The D.C. Court of Appeals in National Ass'n of Manufacturers $v$. SEC held that the requirement to list a product as containing DRC Conflict Minerals was not narrowly tailored because there is no "evidence that alternatives would be less effective," and thus it is unconstitutional. ${ }^{52}$ While this holding does not invalidate reporting requirements or affect the primary objective of Section 1502 , it is detrimental to the law's underlying enforcement mechanism of using negative publicity and shame to deter issuers from using minerals that they have reason to believe originated from conflict mines.

Following the court's decision in National Ass'n of Manufacturers, the director of the SEC issued a statement on the decision. He wrote, pursuant to the court's decision, "[n]o company is required to describe its products as 'DRC conflict free,' having 'not been found to be DRC

46. Id. at 56,281 .

47. 15 U.S.C. $\$ 78 \mathrm{~m}(\mathrm{p})(1)(\mathrm{A})(\mathrm{ii})$.

48. Id.

49. See 15 U.S.C. $\S 78 \mathrm{~m}(\mathrm{p})(1)(\mathrm{E})$.

50. See Christiana Ochoa \& Patrick J. Keenan, Regulating Information Flows, Regulating Conflict: An Analysis of United States Conflict Minerals Legislation, 3 GEOTTINGEN J. INT'L L. 129, 146 (2011).

51. See Nat'l Ass'n of Mfrs., 748 F.3d at 371 (holding that "by compelling an issuer to confess blood on its hands, the statute interferes with that exercise of the freedom of speech under the First Amendment").

52. Id. at 373 . 
conflict free,' or 'DRC conflict undeterminable."'53 As a consequence of this decision, on May 2, 2014, the SEC stayed the effective date for compliance with the public disclosure component of the Final Rule, pending the completion of judicial review. ${ }^{54}$

As for the remaining components of the law, much debate has revolved around the economic impact this three-step process will have on the United States and the strict demands this will place on businesses unfamiliar with tracing raw materials. Further, many doubt whether the SEC is the appropriate organization to develop the rules for Section 1502, or whether the SEC has the appropriate resources or capabilities to verify whether a particular business is in compliance with the new regulation. Although these domestic implementation concerns will be discussed briefly, the primary objective of this Note is to analyze the consequences of the legislation and to argue there is a need for an extraction-level companion that will empower Section 1502 by regulating trade on the front end, thereby promoting the objective of Dodd-Frank and easing the law's demands on U.S. businesses.

\section{B. The Economics of the Problem}

Now, although many businesses are charged with the burden of tracing minerals they acquire from Eastern Africa, there is a major human rights interest that counterbalances the economic encumbrance. The events concerning human rights activists in the Congo are externalities of the international trade of these minerals, and they demand a great deal of consideration when legislators are determining whom to protect.

In response to the humanitarian emergency in the Eastern Congo, it was the U.S. Congress's sense that "the exploitation and trade of conflict minerals originating in the Democratic Republic of the Congo is helping to finance conflict characterized by extreme levels of violence in the eastern Democratic Republic of the Congo, particularly sexual- and gender-based violence, and contributing to an emergency humanitarian situation therein . . .."55 Rather than ignoring this humanitarian crisis, policy makers acknowledged: "America's actions in the world are a powerful demonstration of what it wants to accomplish with its power

53. Keith F. Higgins, Statement on the Effect of the Recent Court of Appeals Decision on the Conflict Minerals Rule, SEC.Gov (Apr. 29, 2014), http://www.sec.gov/News/PublicStmt/ Detail/PublicStmt/1370541681994\#.U9-B615YVg0.

54. Exchange Act Rule 13p-1 and Form SD, Exchange Act Release No. 72079, 2014 WL 1744128 (May 2, 2014) (order issuing stay).

55. H.R. 4173, 111th Cong. $§ 1502$ (2010) (enacted). 
and the values it wishes to uphold." 56 Therefore, in addressing issues of global hardship, Congress took instrumental morals into consideration. ${ }^{57}$

Consequently, Congress believed that the human rights interest in and of itself outweighed the economic interests of U.S. businesses. Congress's ultimate passage of the law illustrated the favoring of the interests of the destitute and exploited Congolese. However, if this bill were found to have no impact on reversing the human rights violations in the DRC - that is, despite regulation of U.S. trade practices, no change resulted-would the balance then be tipped in favor of corporate economic interests?

The humanitarian crisis delineated above is concerning. Whether it is attributable to local culture, ethnic conflict, or corporate interests, we can invoke Law and Economics theory to deconstruct this problem and to understand whether these deadly externalities are exacerbated by regulation in the United States. This analysis is critical to prescribe the appropriate remedy to the intractable violence in the Congo.

\section{Coase Theorem}

Ronald Coase developed a theory in 1960 as a means to understand how efficiently costs are allocated in the event that transaction costs are decreased or eliminated entirely. ${ }^{58}$ This concept is best illustrated through an example:

Consider a factory whose smoke causes damage to the laundry hung outdoors by five nearby residents. In the absence of any corrective action each resident would suffer $\$ 75$ in damages, a total of $\$ 375$. The smoke damage can be eliminated in either of two ways: a smokescreen can be installed on the factory's chimney, at a cost of $\$ 150$, or each resident can be provided an electric dryer, at a cost of $\$ 50$ per resident. The efficient solution is clearly to install the smokescreen because it eliminates total damages of $\$ 375$ for an outlay of only

56. Derek Chollet \& Tod Lindberg, A Moral Core for U.S. Foreign Policy: Is Idealism Dead?, in AMERICAN FOREIGN POLICY, supra note 31, at 598, 610.

57. See id.

58. See A. Mitchell Polinsky, AN InTROduction to LAW AND ECONOMics 13 (4th ed. 2011). 
$\$ 150$, and it is cheaper than purchasing five dryers for $\$ 250.59$

One can draw many parallels between Coase's example and the DRC conflict to determine what an efficient solution could be. For example, let us equate the smoke in the previous example to the conflict in the DRC. Although some may attribute the violence in the Congo to tribal warfare, most understand that the violence comes from intense competition among the rebel factions to sell these profitable minerals to Western corporations. Congress found that this "smoke" has led to death, chronic malnutrition, and sexual assault. These costs lead to an amount of damages that can hardly be assigned a dollar figure; returning to Coase's illustration, the "smoke" leads to residents suffering extreme damages, the cost of which far exceed the costs corporations would bear by complying with regulations. Therefore, it is Congress's intent to require corporations to install a "smokescreen," or in our case a reporting mechanism, that cleans up corporate supply chains. Indeed, because the Congolese are unable to purchase a "dryer" to ameliorate their conditions the efficient solution would be to regulate the manufacturer (e.g., U.S. corporations with supply chains linked to conflict mines).

Any analysis of the most efficient way to reduce damages must take into consideration its associated transaction costs. These costs include "identifying the parties with whom one has to bargain, the costs of getting together with them, the costs of the bargaining process itself, and the costs of enforcing any bargain reached." 60 When a company qualifies under the statute as an issuer the costs then associated with effective compliance of the statute become quite burdensome. Under step one of the SEC rule, corporations must determine whether or not they are subject to the regulation. ${ }^{61}$ This determination requires transaction costs and legal fees. If it is subject to the regulation, a corporation must incur a second cost of tracing the corporate supply chain back to the origin of the mineral being used for production. The substantial third cost requires the company to pay significant legal fees to ensure compliance with the regulation.

Still, it seems clear that, due to the substantial costs suffered by the Congolese, the efficient solution resides with regulating the "factory," or in our case, U.S. corporations. However, whereas Congress implemented the requirement of "smokescreens" (or supply chain reporting) only for issuers, the regulation should broaden its focus to also influence

59. Id.

60. Id. at 14 .

61. Conflict Minerals, 77 Fed. Reg. at 56,274. 
changes within the Congolese mining sector. This additional regulatory requirement will be discussed later in this Note as the grassroots solution.

\section{Tragedy of the Commons}

A second Law and Economics theory that applies to the Congo is the tragedy of the commons, an idea coined by Garrett Hardin in 1968.62 As with the previous theory, the idea is most easily understood through Hardin's classic example:

The tragedy of the commons develops in this way. Picture a pasture open to all. It is to be expected that each herdsman will try to keep as many cattle as possible on the commons. Such an arrangement may work reasonably satisfactorily for centuries because tribal wars, poaching, and disease keep the numbers of both man and beast well below the carrying capacity of the land. Finally, however, comes the day of reckoning, that is, the day when the long-desired goal of social stability becomes a reality. At this point, the inherent logic of the commons remorselessly generates tragedy. ${ }^{63}$

In the context of the DRC, this "day of reckoning" has arrived due to the exposure of human rights violations in the region. For centuries, individuals have sought to maximize their gain in Eastern Africa, always at the expense of local Congolese interests. Today, both Congolese militant groups and international corporations seek to maximize their gains. With the abuse of these "commons" and the arrival of the "day of reckoning," the time is now ripe to impose regulatory measures on the ground in the Congo that slow or halt the ongoing tragedy of the commons. What regulation is sufficient to end this tragedy?

This Note argues that Section 1502 falls short of its intended objectives and insufficiently attends to human rights interests. Although Section 1502 was not intended to be an all-encompassing solution, it was expected to reduce violence. Therefore, unless Section 1502 is proven effective in curbing violence in the DRC, Section 1502 will lose its muster, and corporate economic interests will then

62. See generally Garrett Hardin, The Tragedy of the Commons, 162 SCIENCE 1243

(1968) (introducing the theory of the "tragedy of the commons").

63. Id. at 1244 . 
overpower the human rights interest associated with the statute. To prevent this rebalancing of interests, Congress should have involved the Congolese and lobbied for more powerful extraction-level regulation to have been implemented in the DRC at the time Section 1502 was legislated. Even after such legislation was passed, the SEC should have sought specialized Congolese insight during the notice and comment time of the rulemaking. Nevertheless, regulation within the DRC would ensure that Congolese efforts acting in conjunction with the trade-level solutions would effectively promote regional security and reduce human rights violations. If implemented, an extraction-level solution would secure Congress's objectives, thereby legitimizing and bolstering Section 1502.

\section{Resource Curse}

Implicit in the legislating of Section 1502 is a particular worldview that explains why destitution and violence are intractable in SubSaharan Africa. Behind legislation as aggressive as Section 1502, Congress responded to the Congolese crisis with a regulation that attempts to cure a resource curse. In a country like the DRC, where prosperity remains an illusion despite widespread mineral wealth, the resource curse is a theoretical phrase adopted to explain the relationship between resource wealth and economic poverty. ${ }^{64}$ Economic experts propose four approaches to this curse. Through understanding these theories, we may better understand the worldview on which Congress has legislated, thus providing an understanding on which Congolese efforts may respond to Section 1502 in a complimentary fashion.

The first approach is the Dutch disease approach. ${ }^{65}$ This theory seeks to understand the relationship between booms in one market and contractions in another. "Increases in resource-based revenues, such as oil, generate a greater capacity to import tradable goods, but typically prompt a greater demand for all goods including non-tradables, which cannot be imported but must be produced locally." 66 Thus, a boom in one market would lead to a contraction in other markets such as

64. See generally RICHARD M. AUTY, SUSTAINING DEVELopMENT IN Mineral ECONOMIES: THe RESOURCE CURSE THESIS (1993) (introducing and discussing the resource curse).

65. Ricardo Hausmann \& Roberto Rigobon, An Alternative Interpretation of the 'Resource Curse': Theory and Policy Implications 4 (Nat'l Bureau of Econ. Research, Working Faper No. 9424, 2002).

66. See id. 
manufacturing. ${ }^{67}$ This model holds that in the midst of these booms, labor migrates from one industry to another, decreasing the amount of time that employees have to specialize and accumulate specific knowledge within an industry. ${ }^{68}$ In the meantime, more stable economies continue to advance. ${ }^{69}$ Although this approach may seem helpful, it was not the view under which Congress operated when creating Section 1502. Congress attempted to legislate in response to a humanitarian crisis, not to regulate and influence market booms and contractions.

A second theory that could explain the resource curse is the rentseeking approach. Here, theorists argue that resource wealth such as oil makes societies less entrepreneurial, thus discouraging growth. ${ }^{70}$ Under these circumstances, a plethora of national resource wealth incentivizes rent-seeking activities rather than wealth-creating entrepreneurial opportunities. Thus, individuals who would otherwise pursue entrepreneurial opportunities instead rely on lucrative benefits enjoyed by government positions that regulate the nation's natural resources. ${ }^{71}$ This theory seems to match the Congolese story; however, this rentseeking approach does not seem to be the theory under which Congress has legislated because the purpose of Section 1502 is not to create entrepreneurial opportunities. Although this theory is compelling for the Congolese scenario, Congress did not operate under the rent-seeking approach.

A third theory is the volatility story. Under this theory, natural resource rents tend to be very volatile because the supply of natural resources exhibits low price elasticity of supply. ${ }^{72}$ Although these resources may be profitable at any given time, this volatility is bad for growth, investment, income distribution, and educational attainment. ${ }^{73}$ The minerals that Section 1502 regulate are generally volatile in the marketplace. However, the actions of Congress were not driven by a desire to shield the Congolese economy from volatile international markets. Rather, the purpose of Section 1502 is to alleviate "extreme levels of violence in the eastern Democratic Republic of the Congo, particularly sexual- and gender-based violence ...."74 Therefore, the

67. See id.

68. See Kiminori Matsuyama, Agricultural Productivity, Comparative Advantage, and Economic Growth, 58 J. ECON. THEORY 317, 328 (1992).

69. See id.

70. Hausmann \& Rigobon, supra note 65 , at 7 .

71. Id.

72. Id. at 9.

73. Id.

74. H.R. 4173. 
volatility theory must not have been the motivating theory behind Section 1502.

The fourth and final theory is the deprivation theory. This approach argues that it is the influx of foreign capital and investment that accentuates differences in ruling classes and increases inequality in the distribution of income and wealth. ${ }^{75}$ This theory argues,

[T] $\mathrm{T}$ e presence of foreign capital in the poor country creates a domestic ruling elite that is dominated by foreign interests. As the argument goes, the domination of the national elites by the executives of multinational companies is due partly to the fact that manufacturing and mining investment, which the African ruling elites consider to be very critical to their development, places the owners of foreign capital in a position to have enormous control over public policy in the country in question . . . ${ }^{76}$

The deprivation theory appears to be the worldview under which Congress adopted Section 1502. By regulating U.S. corporations and restricting trading practices, Congress intended to reduce the U.S. footprint on the Congolese conflict. Congress seemed to believe that trade in this region "exacerbat[ed] existing inequalities and inequities in the distribution of resources, and as a result, levels of domestic political conflict [rose]."77 The unintended consequence of Section 1502, however, is that it "has inadvertently and directly negatively affected up to 5-12 million Congolese civilians." 78 Miners are now unemployed and unable to feed their families. Therefore, under the view that corporate participation in trade exacerbates conflict, Section 1502 attempts only to modify external influences in the Congolese conflict and fails to consider circumstances that must first change within the DRC.

75. See John Mukum Mbaku, Economic Development in Africa, in AFRICA AND THE Third MiluenNium 87, 125 (George Klay Kieh, Jr. ed., 2008).

76. Id. at $125-26$.

77. Id. at 126 .

78. Seay, supra note 3 , at 15 . 


\section{TO REVERSE THE EFFECTS OF THE CURRENT RESOURCE CURSE THERE Must Be a Trade LeVel Solution (SECTION 1502) Coupled With A GRASSROOTS EXTRACTION-LEVEL SOLUTION}

Experts forecast the demise of Section 1502's objectives based on several of its perceived failures. The shortcomings listed below are not exhaustive, nor are they intended to be reasons for repealing Section 1502. Rather, they reveal an obvious void in fulfilling the objective of securing economic stability and social tranquility for the Eastern Congo, and call for that void to be filled by an African initiative.

The first and most often cited unintended consequence of Section 1502 is the cost of implementation, which is estimated to be around $\$ 7.93$ billion. ${ }^{79}$ This estimate reflects the costs for businesses to implement traceability reforms, personnel time, third party consulting, information technology systems, and audits. ${ }^{80}$ This provision of DoddFrank alone will affect over 6,000 U.S. businesses, each required to trace minerals to a conflict-free zone (an expensive and many times impossible task). ${ }^{81}$ The expense of tracing comes from the complex framework through which these minerals travel to reach their destination; I provide a cursory overview of the supply chain in the following section.

Observers have documented that minerals pass through at least ten intermediaries from supply to ultimate consumption as a finished consumer product. ${ }^{82}$ Such minerals, like coltan, are first mined by small, independent operations that then sell the minerals to petits négociants (or small traders in Congolese French) near the mining site. The négociants then use porters to deliver the minerals to local villages where they sell the product to comptoirs. ${ }^{83}$ Comptoirs are the intermediaries who export the product to processing facilities in China, Germany, or the United States. ${ }^{84}$ These comptoirs often knowingly purchase coltan from areas controlled by armed groups and exploit the

79. Chris Bayer, A Critical ANalysis of THE SEC AND NAM ECONOMic IMPaCt MOdELS AND THE PROPOSAL OF A 3RD MODEL IN VIEW OF THE IMPLEMENTATION OF SECTION 1502 OF THE 2010 DODD-Frank WALl STREET REForm AND CONSUMER PROTECTION ACT 32 (Oct. 17, 2011), http://payson.tulane.edu/sites/default/files/ 3rd_Economic_Impact_Model-Conflict_Minerals.pdf.

80. See id at 3 .

81. ERnst \& Young, Conflict Minerals: What You NeEd to KNOW ABout THE NEW Disclosure and REPORTING REQUiREMENTS AND How ERNST \& Young CAN Help 1 (2012).

82. Tiffany Ma, China and Congo's Coltan Connection, Project 2049 Institute, FUTUREGRAM 09-003, 3 (2009).

83. Id.

84. Id. 
distinction between themselves and négociants in order to claim lack of knowledge over the mineral's origin. ${ }^{85}$ With such a dense network of trade occurring internally within the DRC, it is difficult to expect U.S.based companies to untangle the web and detect the exact origin of the mineral. This would require these companies to account for trade networks that are not clearly understood even by experts in the Congo. However, as discussed below, an extraction-level certification process would reduce such due diligence costs and clear up the supply chain.

The second shortcoming of Section 1502 is the lack of infrastructure within the SEC to adequately validate whether a reporting company is in compliance with Section 1502 regulations. Section 1502 is a "complex matter beyond the SEC's normal area of expertise. The SEC's mission is to protect investors; maintain fair, orderly, and efficient markets; and to facilitate capital formations. This Section does not protect investors or provide information about the financial health of companies." 86 Others believe that Section 1502 is within the scope of congressional power, because the primary function of the SEC is investor protection. "The Foreign Corrupt Practices Act was enacted to protect investors and the integrity of markets. Section 1502 was enacted for the same reason and in the same spirit." 87 However, the more pressing question is not whether Section 1502 is within the authorized legal scope of the SEC, but whether this is a matter that the SEC has the appropriate resources, expertise, and capabilities to regulate. Many argue that this requirement "stretches thin an already overburdened agency and demands that it oversee diplomatic and humanitarian regulations for which it lacks the institutional competence."88

A third critique, which is of much concern for this Note, is that Section 1502 does not, by itself, meet the needs of its intended objectives. Historically, Congress has acted unilaterally to influence change in a foreign nation without first requiring the passage of new substantive regulation within that country itself. An example of this strategy was Congress's attempt to influence conflict in Nicaragua by supporting the contras through economic actions.

85. Id.

86. The Costs and Consequences of Dodd-Frank Section 1502: Impacts on America and The Congo: Hearing Before the Subcomm. on Int'l Monetary Policy and Trade of the $H$. Comm. on Fin. Serv., 112th Cong. 2 (2012) [hereinafter Hearings] (statement of Rep. Gary G. Miller, Chairman, Subcomm. on Int'l Monetary Policy and Trade).

87. Id. at 6 .

88. Karen E. Woody, Conflict Minerals Legislation: The SEC's New Role as Diplomatic and Humanitarian Watchdog, 81 FORDHAM L. REV. 1315, 1342 (2012). 
The U.S. government has mounted a trade embargo against Nicaragua which has made life yet more difficult for the civilians already victimized by the contra war. . . . Washington has done little or nothing to ensure that humanitarian assistance from private organizations be made available to the victims of government violence in Guatemala and El Salvador. It has, in fact, obstructed such aid. ${ }^{89}$

In Nicaragua, as in the DRC, regulations designed in Washington to facilitate change in a foreign country often result in unintended consequences.

Such unintended consequences are beginning to emerge in the DRC. Following the implementation of Dodd-Frank, President Joseph Kabila of the DRC instituted a ban on all mining in the Kivu and Maniema provinces. ${ }^{90}$ This ban "increased [the] militarization of the mining sector as the Congolese national army, the FARDC, took over many mines that had previously been non-militarized."91 Kabila's ban would not have been instituted without Section 1502.92 This ban had substantial humanitarian effects on the Eastern Congo region that worsened the humanitarian crisis rather than alleviating suffering. While the United Nations Group of Experts considered similar sanctions in 2006, a wellrespected advocacy group "examined the potential humanitarian fallout from such sanctions and warned that [they] could hurt the livelihoods of as many as 2 million artisanal miners and their families . . .."93 In a nation with low economic opportunity and capability, the unemployment of an additional two million workers would have severe ramifications for families that would now be unable to afford food or school fees.94 Unfortunately, the U.N. estimation became reality. During President Kabila's ban, only three of Goma's twenty-five exporters were operating and employing miners, and they were selling to the Chinese rather than to the United States. ${ }^{95}$

89. Inter-Hemispheric Educ. Res. Ctr, Public and Private Humanttarian Aid: LEGAL AND ETHICAL ISSUES 18 (1988).

90. Seay, supra note 3 , at 13 .

91. Id.

92. $I d$.

93. The Enough Project \& The Grassroots Reconciliation GrP., A COMPREHENSIVE APPROACH TO CONGO'S CONFLICT MiNERALS 1 (2009), http://www. enoughproject.org/files/Comprehensive-Approach.pdf.

94. See AmarTya SEN, Development As FREeDOM 87-110 (2000) for a discussion on the relationship between relative income inequality and economic volatility in underdeveloped nations.

95. Seay, supra note 3 , at 14 . 
Further still, from a corporation's perspective, the main consequence of a company's lack of compliance with Section 1502 is that the company is publicly shamed for its trade practices. ${ }^{96}$ So, even today with the ban lifted, U.S. companies unable to sort legitimate from illegitimate minerals, and thus uncertain whether they are in full compliance with Section 1502, will likely choose to withdraw from the country rather than face a public relations disaster. In other words, to avoid the shaming mechanism of Section 1502, U.S. corporations will withdraw from the Eastern African mining market. Therefore, even without an official ban on mining, Section 1502, and the disincentives it places on U.S. businesses to trade in the region, creates "a de facto embargo that is in practice identical to imposing international sanctions against Congolese minerals." 97

Nevertheless, despite these shortcomings put forth by opponents of Section 1502, the law is well-intended and offers a starting place for effectuating change. Although companies are required to file reports with the SEC to comply with Section 1502, the regulation does not prohibit companies from continuing their existing trade practices. ${ }^{98}$ Rather, Section 1502's purpose is to extract information, making companies' supply chain practices in the Eastern Congo publically available so that consumers may then appropriately apply pressure in areas where a company must change. ${ }^{99}$ In this sense, Section 1502 is limited to reputational consequences rather than economic ones.

Furthermore, Section 1502 is designed not just to extract information from companies who oftentimes are unfamiliar with the origins of their minerals, "but also to extract information from their supply chain, all the way to the mine of origin - [thus,] finding the conflict." 100 Therefore, without requiring actual changes in corporate practices, this regulation uniquely acquires information about the actual trading of conflict minerals; doing so informs U.S. consumers and appropriately regulates an industry. ${ }^{101}$

However, there must be a mechanism to prevent the de facto embargo that threatens the livelihood of those we intend on protecting. The proposed solution discussed later in this Note will make reporting to the SEC easier, thereby encouraging businesses to continue trade

96. Woody, supra note 88 , at 1344 .

97. See Shannon Raj, Blood Electronics: Congo's Conflict Minerals and the Legislation that Could Cleanse the Trade, 84 S. CAL. L. REV. 981, 993 (2011).

98. See id. at 1014 .

99. See Ochoa \& Keenan, supra note 50 , at 140.

100. See id.

101. See Milton Friedman \& Rose D. Friedman, Free to Choose: A Personal STATEMENT (1990), for a discussion on the relationship between duties a government owes its citizens and the market it is charged with regulating. 
with the DRC and allowing mining operations to continue. As crafty and helpful as Section 1502 may be, this Note is concerned with the failure of Congress and the SEC to engage with the Congolese civil society to recognize and empower grassroots, extraction-level solutions that share the same objectives as Section 1502. With a paternalistic undertone, Congress has attempted to address the Congolese crisis with an international top-down approach rather than communicating with and empowering similar efforts on the ground.

Before discussing the need for a strong extraction-level solution, this Note must first acknowledge another proposed solution, the customsbased approach. This approach traces minerals from the point of export from the country back to the mine. ${ }^{102}$ Functionally, this solution is the same as this Note's proposed trade-level solution; however, the customsbased approach stops short of tracing the chain of custody back to the point of origin. In failing to trace from the mine itself, the problem will not be remedied at its root. Rather, by regulating the early stages of the supply chain, officials can accurately rely on certainty about the source of the exported minerals. Additionally, the customs-based approach is ineffective because it does not utilize the forces already acting in the current mineral mining market.

Another problem with this approach is that it threatens those who violate such laws with criminal prosecution; however, the Kivu region of the Congo essentially has no effective rule of law, ${ }^{103}$ so legal threats of incrimination fall on deaf ears and provide no effective deterrence.

The state exercised no sovereignty over North Kivu between 1998 and 2008 - a vacuum ensured the anarchical condition. State failure provides the limiting case for understanding how individuals respond to violence when they cannot turn to a neutral authority for safety and security. In an anarchical environment free from institutional restraint, individuals "often seek safety, profit, or both."104

Therefore, rather than threatening with toothless laws, legislators should empower and legitimize current role models who trade minerals ethically in and around the DRC. To do this, we must start at the point of extraction.

102. Raj, supra note 97 , at 1014-16.

103. See Dominic Burbidge, The Security Dilemma In North Kivu, The Democratic Republic of the Congo, 3 CONFLICT TRENDS 42, 44 (2009).

104. Id. 


\section{SECTION 1502's NEED FOR A GRASSROOTS EXTRACTION-LEVEL COMPANION}

During the 1970s, top-down approaches were increasingly recognized as having only limited success in reducing poverty in parts of the world. ${ }^{105}$ Failing to "trickle down" to the poorest in the world, such benefits rarely made it to the intended beneficiaries. ${ }^{106}$ In addressing these failures, policy makers began to adopt more grassroots solutions, not to replace existing top-down prescriptions, but to instead supplement them. ${ }^{107}$ However, policymakers in foreign nations are not in the best position to implement grassroots solutions. Rather, civil society and Non-Governmental Organizations (NGOs) are considered the most organized and best-equipped forces for representing a grassroots initiative. ${ }^{108}$ NGOs can provide services that are more appropriate to local communities; they are able to provide such services more efficiently and effectively through drawing on local knowledge and using local materials. Finally, NGOs are beneficial to nonmaterial, and thus more difficult to quantify, aspects of "development," particularly processes of empowerment, participation, and democratization. ${ }^{109}$ Likewise, civil society must be included because it is most intimately involved with the Congolese. "Civil society often provides alternatives to non-existent public services and contributes greatly to the population's survival by its local developmental achievements. . . . [Civil society] is an asset on which any conflict resolution efforts will need to rely."110

More important than including NGOs and civil society in reforming the intractable Congolese conflict is the inclusion of the actual Congolese people during the process. Unfortunately, neither Congress in its drafting of Section 1502 nor the SEC in its rulemaking process for Section 1502 consulted with Congolese authorities or mining laborers, the very people whom this law intended to protect. In October 2011, no Congolese were

invited to speak at the SEC's public roundtable on DoddFrank Section 1502, [held] . . . in Washington D.C. . . By failing to engage the Congolese in an honest dialogue on the relationship between conflict and mining, proponents of Section 1502 failed to spur a national

105. Katie Willis, Theories and Practices of Development 93 ( $2 \mathrm{~d}$ ed. 2011).

106. See id.

107. See id. at 93-95.

108. See id. at 98.

109. Id. at 99.

110. INT'L CRISIS GRP., supra note 26 , at 30 . 
ownership of the initiative through a true partnership with the Congolese. ${ }^{111}$

In considering Congolese interests and involving the Congolese people to fulfill Congress's stated intentions, we must understand that there is a preexisting foundation in the Congo for grassroots solutions. In failing to include Congolese civil society in Congress's legislative process, Section 1502 has preempted grassroots efforts by authorizing regulation in the United States. Three examples suggest that changes at the local and domestic level were already underway in the Congo that Section 1502 may have interrupted.

First, the Ndandula Report recently exposed the Organization of the Petroleum Exporting Countries (OPEC) for exploitation of mineral resources. ${ }^{112}$ This report led to a "comprehensive review of mining contracts" in the Kivu region of the Eastern Congo that could essentially change the way that businesses acquire minerals. ${ }^{113}$ Second, the Congolese Parliament "pushed for the restructuring of the Chinese barter investment deal, reducing its terms and downgrading its value from $\$ 9$ billion to $\$ 6$ billion," thus changing trade relationships at the national Congolese level.114 Third, Parliament has been in partnership with Open Society Foundation ${ }^{115}$ in setting the guidelines for the new mining code that will be enacted in the near future. ${ }^{116}$ Therefore, in failing to consider approaches already underway, Congress may have inadvertently stunted Congolese grassroots actions.

In proposing an extraction-level solution, the next section will explain the trading system in the Congo and how existing grassroots efforts in tandem with Section 1502 may help finally curb the violence. Then, this Note will discuss regional challenges to consider in the implementation of regulations. And finally, this Note details recommendations for a solution.

111. Hearings, supra note 86 , at 160 (statement of Mvemba Phezo Dizolele, Stanford Univ.).

112. Id. at 11 .

113. Id.

114. Id.

115. Open Society Foundation's mission is to "work to build vibrant and tolerant democracies whose governments are accountable to their citizens." OPEN SOCIETY FOUNDATION, http://www.opensocietyfoundations.org/about (last visited Apr.14, 2014).

116. Id.; See also Mvemba Dizolele, DRC Needs Security Sector Reform Not Dodd-Frank, OPEN SOCIETY INITIATIVE FOR SOUTHERN AFRICA (May 30, 2012), http://www.osisa.org/ economic-justice/blog/drc-needs-security-sector-reform-not-dodd-frank (arguing that the "current mining code, which was written over a decade ago as part of a World Bank project, disproportionately favours foreign investors at the expense of the Congolese State and the Congolese people"). 
By failing to consult with the Congolese people and to consider initiatives already underway, Congress prematurely passed incomplete legislation that lacked regard for the circumstances within the Congo. In fact, there are developments in the Congolese efforts that must be acknowledged by Section 1502 . According to mining sector regulations passed in 2011 by the Congolese, mining police have been deployed throughout the country to protect mines from combatant organizations. ${ }^{117}$ Further still, the Governor of North Kivu established "a mine monitoring committee tasked with compiling an inventory of traders and investigating fraudulent activities associated with" the illegal trade of minerals. ${ }^{118}$ Thus, grassroots efforts have already begun to lay a foundation on which an efficient certification process may work in conjunction with Section 1502 regulations.

Additionally, a certification process can envelop networks that already exist within the mining industry. In the current trading system, minerals pass through at least ten intermediaries (négociants, comptoirs, etc.) from supply to consumption. ${ }^{119}$ Rather than encouraging U.S. companies to leave the Eastern Congo altogether, as Section 1502 does, interested parties should complement Section 1502 by taking advantage of the existing trade system and integrating the négociants and comptoirs into an authenticating certification process.

It seems intuitive that regulatory officials and Congolese state institutions must target the négociants, the parties most attuned to the mines and the mining practices. However, a practical regional problem to consider is corruption. Transparency International has ranked the DRC 154 out of 177 countries on the Corruption Perceptions Index. ${ }^{120}$ Most concerning for purposes of mining in the Eastern Congo is the DRC ranking only in the third percentile on the Control of Corruption index. ${ }^{121}$ This raises a greater flag for the proposed certification process because this index suggests that corruption exerted over the nation's

117. U.N. Group of Experts, supra note 17, at 110.

118. Id. at 112 .

119. Ma, supra note 82 , at 3 .

120. Corruption by Country/Territory, TRANSPARENCY INTERNATIONAL, http://www. transparency.org/country\#COD (follow "?" hyperlink to right of "Corruption Perception Index") (last visited Jan. 12, 2014) ("The Corruption Perceptions Index ranks countries/territories based on how corrupt a country's public sector is perceived to be. It is a composite index, drawing on corruption-related data from expert and business surveys carried out by a variety of independent and reputable institutions.").

121. Corruption by Country/Territory, TRANSPARENCY INTERNATIONAL, http://www. transparency.org/country\#COD (follow "?" hyperlink to right of "Control of Corruption") (last visited Jan. 12, 2014) ("Control of corruption reflects perceptions of the extent to which public power is exercised for private gain. This includes both petty and grand forms of corruption, as well as 'capture' of the state by elites and private interests."). 
natural resources is one of the worst in the world. Such corruption makes it difficult to construct an efficient regulatory body over the mines in Eastern Congo.

Severine Autesserre, an expert on the DRC, found that "national actors also often participated in the illegal exploitation of natural resources in the eastern provinces." 122 A number of Congolese armies have become involved in mining. "Soldiers either dug minerals or taxed the local production, while the officers both facilitated and benefited from illegal exportation to Rwanda, Tanzania, or Uganda." ${ }^{123}$ Thus, unregulated government officials, who often succumb to economic temptation (rent-seeking), should not be charged with regulating the négociants. In combating the continued threat of rent-seeking, the African Union, or a coalition of the governments of the Covered Countries must form a neutral certifying body.

In utilizing the existing trade framework while considering the threat of corruption, this Note recommends a certification process that is similar in some aspects to the Kimberley Process, which was adopted for the trade of conflict diamonds. ${ }^{124}$ Through the cooperation of the a coalition of governments, civil society, NGOs, and stakeholders, the African Union should develop a certification process whereby regional certification offices would be responsible for certifying particular minerals before they leave the mines. These offices would work through négociants; however, for négociants to operate in Congolese mines, they must be certified and attend quarterly training sessions held by the certification offices proposed herein.

Karen Woody has proposed implementing a Kimberley-like process in the Congo; however, her article fails to recognize the utility of maintaining Section 1502 even if such a certification process were implemented. ${ }^{125}$ It is critical that Section 1502 would remain intact if such a certification process existed because there must still be a regulatory scheme in the United States by which U.S. consumers have

122. SÉverine AUTESSERRe, THe TROUBle With the CONGO: LOCAL ViolenCe AND the FAILURE of INTERNATIONAL PEACEBUILDing 64 (2010).

123. Id.

124. Clive Wright, Tackling Conflict Diamonds: The Kimberley Process Certification Scheme, 11 INT'L PEACEKEEPING 697, 699 (2004) ('The Kimberley Process Certification Scheme (KPCS) is not a legally-binding treaty between sovereign states. Rather, it is a set of politically-binding minimum common standards, enacted by each state through its own national legislation... These minimum standards set out the way in which each member of the Kimberley Process handles the import and export of rough diamonds into and from its territory, as well as its internal controls for ensuring that domestic trading and processing are not contaminated by illicit sales. The agreement also stipulates various levels of transparency, monitoring and co-operation between members.").

125. Woody, supra note 88 , at $1347-51$. 
access to information about the origins of a business's minerals. Section 1502 would reinforce the certification process while deterring illegitimate supply processes. Therefore, this process would leave the customs-based approach intact while legitimating Dodd-Frank's tradelevel solution, thus regulating on both the front and back ends.

This certification process would need to differ from the Kimberley process in two respects. First, reports submitted by the regionally located certification offices about mines must be transparent and subject to close scrutiny by auditors. Under the Kimberley Process, "reports written by peer-review groups are classified as confidential" and are not made available "to the larger international community and the public." 126 Second, unlike the Kimberley Process, which requires a self-regulating system within each nation, various actors and entities must participate in the Congolese certification process. In Transparency International's ranking of countries according to respect for "Rule of Law," the DRC only ranks in the second percentile. ${ }^{127}$ Therefore, this proposed certification process requires all hands on deck from NGOs, civil society, and government agencies alike. However, to prevent rentseeking from government agencies, these efforts would also require support from uninterested organizations such as the African Union.

A final aspect of the extraction-level solution is that U.S. businesses, now tasked with tracing minerals to mines to comply with Section 1502, can choose to redirect their tracing expenses to invest in and build this certification process. To encourage this investment, the SEC can defer a corporation's Section 1502 compliance so long as the corporation invested in the certification organization an amount comparable to that which the corporation would have otherwise spent on supply chain due diligence. If a corporation opts to acquire its minerals from another source and pay for the costs associated with Section 1502 compliance, it may do so. However, over time, the growth of capital in the certification organization will be robust enough that the SEC will recognize the organization's certification as sufficient for the Section 1502 reporting requirements. In the long run, businesses would save on costs while contributing to the development of a legitimate authentication process.

126. Sasha lezhnev \& David Sullivan, The Enough Project, Certification: The PATH to CONFLICT-FREE Minerals FROM CONGO 9 (2011), available at http://www. enoughproject.org/files/certification_paper_0.pdf.

127. Corruption by Country/Territory, TRANSPARENCY INTERNATIONAL, http://www. transparency.org/country\#COD (follow "?" hyperlink to right of "Rule of Law") (last visited Jan. 12, 2014) ("This dimension captures perceptions of the extent to which agents have confidence in and abide by the rules of society, and in particular the quality of contract enforcement, property rights, the police, and the courts, as well as the likelihood of crime and violence."). 


\section{CONCLUSION}

Section 1502 is neither the first nor the last time that the United States Congress will attempt to effect change in foreign countries by regulating trade practices in the United States. Therefore, in moving forward, it is crucial to identify the most important variables that Congress must consider in legislating such regulations. As we have seen from the case in the DRC, Congress and administrative agencies should: invite foreign nationals and representatives of civil society into their discussions; consider ongoing efforts on the ground in the targeted country; legitimize existing processes in the targeted nation; and legislate in such a way so as to avoid debilitating de facto bans on the targeted economy.

Dating back to Europe's initial exploitation of the Congo and the Congolese people, the DRC has been treated as a land bountiful with business opportunities rather than a nation with a rich heritage and societal potential. Over time, initiatives in Western nations have attempted to reform these inhumane corporate practices in the Congo. Such initiatives were hailed as human rights milestones, righting the wrongs committed against the Congolese; however, such milestones failed to reform the underlying desire to profit from Congolese land.

The brief look through history in this Note, aided by just a few of the many examples, warns Section 1502 proponents to be wary of reforms aimed only at creating domestic regulations in the United States. As seen from those historical examples, regulations proposed and administered by the Congolese, substantive changes abroad or in the international community do not benefit or improve Congolese circumstances. Therefore, rather than repeating history by advocating only for change outside of the Congo, for once the West should advocate for its reforms to be accompanied by effective laws and regulations within the Congo itself.

To this end, NGOs, civil society, corporations, and the Congolese government should join forces to develop a comprehensive certification process that authenticates minerals and legitimizes their mining origins by using existing négociants and certain established trade practices. Such certification would end the tragedy of the commons in the Congo because mining practices would be legitimized and regulated, and militant organizations would thus be unable to profit. Additionally, certification would expand application of the Coase Theorem to include entities within the Congo as the "factory" subject to regulation, not just U.S. corporations. Finally, this certification process has a forwardlooking solution rather than Section 1502's backward-tracing technique. Thus, with the tracing mechanisms of Section 1502 and this Note's 
certification process, legitimate trade and exportation will encourage U.S. businesses to continue trade with the Congo, prevent de facto embargos, and ensure the use of conflict-free minerals from the Eastern Congo. 